\title{
Implementasi Model Experiential Learning untuk Meningkatkan Kualitas Pembelajaran Biologi Siswa Kelas XI IPA 1 SMA Negeri 2 Surakarta Tahun Pelajaran 2013/2014
}

\author{
Implementation of Experiential Learning Model to Increase Quality \\ of Biology Learning Students in Class XI IPA 1 at \\ State Senior High School 2 Surakarta in Academic Year 2013/2014 \\ Elisa Dewi Yuliarti ${ }^{a}$, Sajidan $^{\text {b }}$, Marjono ${ }^{c}$ \\ ${ }^{a}$ Pendidikan Biologi FKIP UNS, Email: elisadewiyuliarti@yahoo.com \\ ${ }^{\mathrm{b}}$ Pendidikan Biologi FKIP UNS, Email: adjids2002@yahoo.com \\ ${ }^{c}$ Pendidikan Biologi FKIP UNS, Email: marjonobio@yahoo.com
}

Diterima 10 Agustus 2014, disetujui 11 September 2014

\begin{abstract}
The purposes of this research are to increase quality of biology learning considered by utility of facilities in the classroom, classroom climate, and student motivation of achievement in class XI IPA 1 at State Senior High School 2 Surakarta in academic year 2013/2014. This research was a classroom action research which performed in two cycles. Each cycle consisted of 4 phases, that is planning, action, observation, and reflection. Subject of research is students of XI IPA 1 at State Senior High School 2 Surakarta. Data of research was obtained by test and non test technique. Data validation was used triangulation of methods and triangulation of observers. The obtained data were analyzed using descriptive technique. The results of this research showed the average percentage for classroom climate pre cycle $(62,59 \%)$, cycle I $(75,86 \%)$, and cycle II $(82,92 \%)$; student motivation of achievement pre cycle $(63,22 \%)$, cycle I $(74,88 \%)$ and cycle II $(78,62 \%)$; and utility of learning facilities in the classroom have been optimally, that are usage of microscope and other learning media included LCD, pictures, and video as a media to support learning activities. The results showed that the average percentage quality of biology learning aspect such as pre cycle $(62,90 \%)$, cycle I $(75,37 \%)$, and cycle II $(80,77 \%)$. The level increase of quality aspect of biology learning from pre cycle to cycle II is $17,87 \%$. The conclusion of this research is that the implementation of experiential learning model can improve quality of biology learning considered by utility of facilities in the classroom, classroom climate, and student motivation of achievement in class XI IPA 1 State Senior High School 2 Surakarta in academic year 2013/2014.
\end{abstract}

Key Words: Experiential learning, Quality of biology learning

\section{Pendahuluan}

Pendidikan merupakan suatu hal yang penting untuk mencetak generasigenerasi penerus bangsa yang berkualitas. Seiring perkembangan zaman, dunia pendidikan memerlukan inovasi-inovasi baru sehingga mutu pen-didikan di Indonesia dapat ditingkatkan. Perbaikan dan pembaharuan dalam bi-dang pendidikan perlu dilakukan untuk meningkatkan mutu pendidikan, sehingga dapat menghasilkan anak didik yang berkualitas. Peningkatan mutu pendidi-kan berkaitan erat dengan proses pembelajaran yang terjadi di sekolah sehingga penyempurnaan proses belajar mengajar perlu untuk dilakukan. Pembelajaran merupakan aspek penting dalam pendidikan karena pengalaman belajar yang dialami oleh siswa selama pembelajaran akan sangat berperan dalam 
pembentukan kemampuan yang selanjutnya akan menentukan mutu pendidikan.

Biologi sebagai ilmu memiliki karakteristik yang berbeda dengan ilmu lain. Perbedaan ini terletak pada kompleksitas komponen yang meliputi produk, proses, dan sikap. Pembelajaran yang baik dalam penerapannya tidak hanya mengutamakan produk melainkan juga proses, di samping itu juga dibutuhkan penanaaman sikap ilmiah.

Berdasarkan hasil observasi pada siswa kelas XI IPA 1 SMA Negeri 2 Surakarta diperoleh bahwa pembelajaran di kelas masih berpusat pada guru atau teacher centered. Guru menjelaskan materi di depan kelas dengan metode ceramah yang disertai media powerpoint. Model pembelajaran yang digunakan guru tersebut cenderung kurang membangkitkan semangat siswa untuk berpartisipasi aktif dalam pembelajara. Kurangnya partisipasi dan keterlibatan siswa dalam pembelajaran menyebabkan minat dan motivasi siswa terlihat masih kurang dalam mengikuti kegiatan pembelajaran. Akibat dari kurangnya minat dan motivasi siswa menyebabkan suasana atau iklim kelas menjadi kurang kondusif. Iklim kelas yang tidak kondusif ini terjadi karena kurangnya interaksi antara guru dengan siswa maupun interaksi antar siswanya.
Pembelajaran yang masih bersifat teacher centered juga dipengaruhi oleh pemanfaatan sarana prasarana pembelajaran yang masih belum optimal, terutama pemanfaatan laboratorium sebagai salah satu sarana yang vital dalam kegiatan pembelajaran biologi. Saat kegiatan pembelajaran yang dilaksanakan bersifat teaacher centered, maka output yang diperoleh kurang optimal. Output yang kurang optimal ini ditunjukkan dengan tingkat pemahaman siswa yang hanya bersifat temporer.

Menurut Hamalik (2008) guru perlu menciptakan suasana lingkungan kelas yang menyenangkan (comportable) dan menunjang (Supportive), sehingga membangkitkan motivasi siswa untuk mencapai hasil belajar yang positif.

Oleh karena itu, diperlukan suatu usaha perbaikan untuk meningkatkan kualitas pembelajaran. Seorang guru dapat lebih kreatif dalam kegiatan pembelajaran dengan menerapkan model pembelajaran inovatif. Model pembe-lajaran inovatif yang relevan dengan pandangan konstruktivis adalah model experiential learning. Trianto (2010) mengatakan bahwa pengetahuan bukan-lah seperangkat fakta-fakta, konsep, atau kaidah yang siap untuk diambil dan diingat, manusia harus mengkonstruksi dan mengambil makna dari pengalaman yang diperoleh. 
Model experiential learning diharapkan dapat menciptakan proses belajar yang lebih bermakna, yaitu siswa mengalami apa yang mereka pelajari. (Mahfud, 2011). Experience is the best teacher, pengalaman adalah guru yang terbaik. Belajar adalah kenyataan yang ditunjukkan dengan kegiatan fisik. (Djamarah dan Zain, 2010). Menurut Kolb (1984) dalam Lalonde (2010) experiential learning mendefinisikan belajar sebagai proses bagaimana pengetahuan diciptakan melalui perubahan bentuk pengalaman.

Experiential learning mampu mengaktifkan peserta didik untuk membangun pengetahuan dan keterampilan serta nilai-nilai juga sikap melalui pengalamannya secara langsung kemudian menuangkannya dalam bentuk lisan atau tulisan sesuai dengan tujuan pembelajaran (Rahayu \& Rohayati, 2013).

Budiman (2011) mengungkapkan bahwa Experiential learning terdiri dari tiga aspek yaitu Pengetahuan (konsep, fakta, informasi), Aktivitas (penerapan dalam kegiatan), dan Refleksi.

Kolb (1984) menyampaikan model Experiential Learning terdiri dari empat fase yaitu: 1) Concrete Experence, menggunakan pengalaman yang sudah dilalui peserta untuk pembelajaran yang lebih lanjut; 2) Reflective Observation, mendiskusikan pengalaman para peserta yang telah dilalui; 3) Abstract Conceptual- ization, proses membentuk reaksi pada pengalaman yang baru menjadi sebuah kesimpulan atau konsep yang baru; 4) $A c$ tive Experimentation, modifikasi perilaku lama dan mempraktikkan pada situasi keseharian para peserta (Rahayu \& Rohayati, 2013).

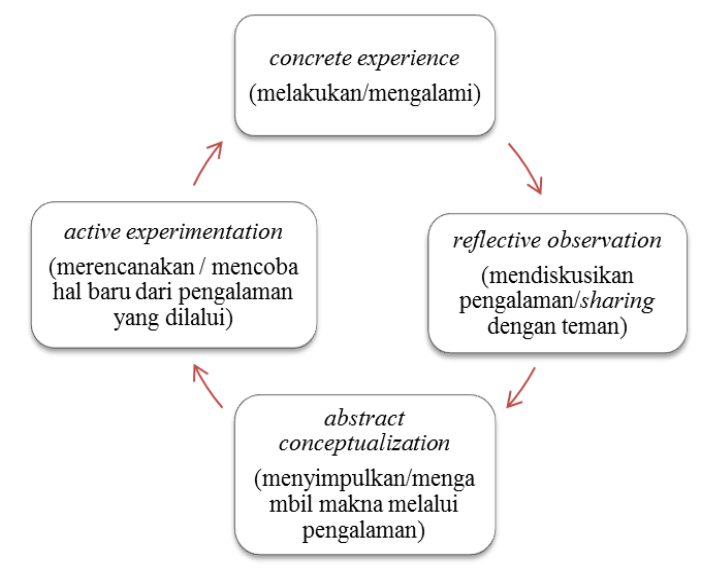

Gambar 1. Siklus Experiential Learning David Kolb (Lalonde, 2010)

Berdasarkan uraian tersebut maka penelitian ini bertujuan untuk meningkatkan kualitas pembelajaran biologi siswa kelas XI IPA 1 SMA Negeri 2 Surakarta melalui implementasi model experiential learning.

\section{Metode Penelitian}

Penelitian ini merupakan penelitian tindakan kelas (PTK) yang bertujuan untuk memecahkan masalah yang timbul dalam kelas dan atau meningkatkan kualitas proses dan hasil pembelajaran di kelas, maka solusinya dibuat berdasarkan kajian teori pembelajaran dan input dari lapangan. Pelaksanaan tindakan tersebut dilakukan dengan cara berkolaborasi 
bersama guru mata pelajaran yang bersangkutan.

Pelaksanaan tindakan berupa implementasi model pembelajaran experiential learning untuk meningkatkan kualitas pembelajaran biologi siswa kelas XI IPA 1 SMA N 2 Surakarta. Dalam menerapkan pembelajaran tersebut, digunakan tindakan berulang/siklus dalam setiap pembelajaran. Statistik yang digunakan dalam penelitian ini adalah statistik deskriptif kualitatif dan dianalisis menggunakan teknik tri-angulasi metode. Data menggambarkan proses pembelajaran yang sebenarnya berlangsung di kelas.

\section{Hasil dan Pembahasan}

Hasil penelitian menunjukkan bahwa implementasi model experiential learning dapat meningkatkan kualitas pembelajaran biologi siswa kelas XI IPA 1 SMA Negeri 2 Surakarta tahun pelajaran 2013/2014.

\section{Kualitas Pembelajaran}

Kualitas pembelajaran adalah bagaimana suatu kegiatan pembelajaran yang dilakukan dapat berjalan dengan baik dan menghasilkan keluaran yang baik pula (Uno, 2008). Kualitas pembelajaran dapat dilihat dari segi proses dan hasil. Dari segi proses, pembelajaran dikatakan berhasil dan berkualitas apabila seluruhnya atau setidak-tidaknya sebagian besar (75\%) peserta didik terlihat aktif, baik fisik, mental maupun sosial dalam proses pembelajaran (Mulyasa, 2007).

Menurut Widoyoko (2010) ada beberapa aspek yang menentukan kualitas pembelajaran yaitu: kinerja guru, fasilitas pembelajaran, iklim kelas, motivasi belajar siswa, dan sikap siswa.

a. Fasilitas Pembelajaran

Peningkatan pemanfaatan fasilitas pembelajaran pada siklus I dan siklus II ditunjukkan oleh penggunaan alat-alat laboratorium seperti mikroskop dan preparat untuk menunjang proses pembelajaran yang dapat membantu siswa membentuk konsep. Media yang digunakan dalam pembelajaran tersebut mampu mengkonkretkan konsep siswa yang terkadang masih abstrak terutama pada materi sistem saraf dan sistem indra.

b. Iklim Kelas

Perbandingan persentase masingmasing indikator dari aspek iklim kelas pra siklus, siklus I, dan siklus II disajikan dalam tabel 1 dan gambar 2 .

Tabel 1. Persentase Capaian Iklim Kelas Pra siklus, Siklus I, dan Siklus II

\begin{tabular}{lllll}
\hline No & Aspek & Capaian & \\
\cline { 3 - 5 } & & $\begin{array}{l}\text { Pra } \\
\text { Siklus }\end{array}$ & Siklus I & $\begin{array}{l}\text { Siklus } \\
\text { II }\end{array}$ \\
\hline 1 & Keterlibatan siswa & $56,91 \%$ & $74,56 \%$ & $83,25 \%$ \\
\hline 2 & $\begin{array}{l}\text { Hubungan antar } \\
\text { siswa }\end{array}$ & $66,51 \%$ & $83,28 \%$ & $86,04 \%$ \\
\hline 3 & $\begin{array}{l}\text { Pertumbuhan dan } \\
\text { perkembangan } \\
\text { pribadi }\end{array}$ & $61,93 \%$ & $70,34 \%$ & $79,76 \%$ \\
& & & \\
\hline 4 & $\begin{array}{l}\text { Perubahan dan } \\
\text { perbaikan sistem }\end{array}$ & $69,42 \%$ & $78,14 \%$ & $82,14 \%$ \\
\hline 5 & $\begin{array}{l}\text { Hubungan antara } \\
\text { siswa dengan guru }\end{array}$ & $58,18 \%$ & $72,95 \%$ & $83,43 \%$ \\
\hline & Jumlah & 312,95 & 379,30 & 414,62 \\
& $\%$ & $62,59 \%$ & $75,86 \%$ & $82,92 \%$ \\
\hline
\end{tabular}




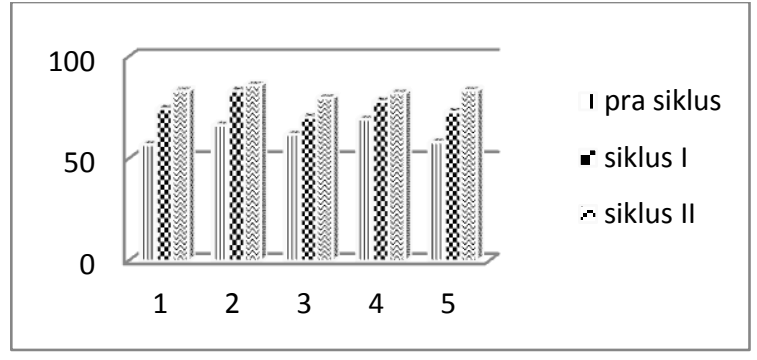

Gambar 2. Perbandingan Persentase Capaian Iklim Kelas Pra Siklus, Siklus I, dan II
Keterangan:
1. Keterlibatan siswa
2. Hubungan antar siswa
3. Pertumbuhan dan perkembangan pribadi
4. Perubahan dan perbaikan sistem
5. Hubungan antara siswa dengan guru

Iklim kelas muncul sebagai akibat hubungan antar siswa maupun hubungan antara siswa dengan guru selama pembelajaran berlangsung (Tarmidi, 2006). Persentase capaian masing-masing aspek iklim kelas berdasarkan tabel dan grafik menunjukkan bahwa iklim kelas XI IPA 1 SMA Negeri 2 Surakarta sudah kondusif. Iklim kelas yang kondusif ini memengaruhi proses pembelajaran yang ada di kelas, sebab iklim kelas yang baik akan menciptakan lingkungan belajar yang menyenangkan bagi siswa. Kemudian, lingkungan belajar yang menyenangkan ini tentunya akan membawa siswa pada situasi dan kondisi yang nyaman untuk belajar sehingga dapat mendukung tercapainya kualitas pembelajaran yang baik.

c. Motivasi Belajar

Perbandingan persentase masingmasing indikator dari aspek motivasi belajar siswa pra siklus, siklus I, dan siklus

II disajikan dalam tabel 2 dan gambar 3.

Tabel 2. Persentase Capaian Motivasi Belajar Pra siklus, Siklus I, dan Siklus II

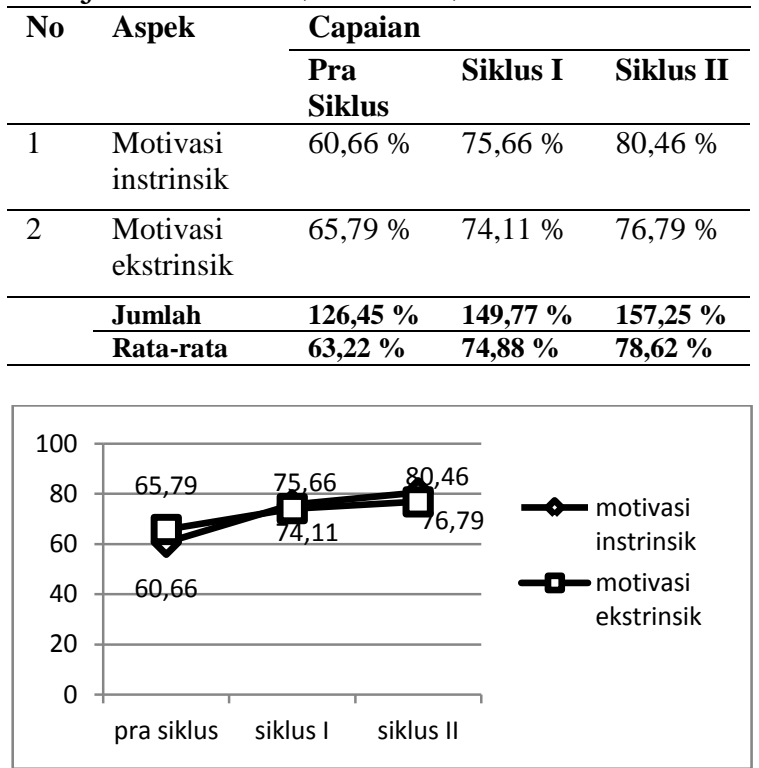

Gambar 3. Perbandingan Persentase Capaian Motivasi Belajar Pra Siklus, Siklus I, dan Siklus II

Motivasi belajar mampu mendorong siswa untuk melakukan suatu kegiatan yang positif selama pembelajaran berlangsung. Atkinson dalam Prawira (2012) menjelaskan bahwa motivasi merupakan suatu tendensi seseorang untuk berbuat yang meningkat guna menghasilkan suatu hasil yang lebih berpengaruh. Motivasi belajar yang tinggi sangat berpengaruh terhadap kualitas pembelajaran siswa.

Motivasi belajar yang tinggi akan akan menciptakan iklim kelas yang kondusif, dan iklim kelas yang kondusif akan mendukung tercapainya kualitas pembelajaran yang maksimal. 
Berdasarkan tabel dan grafik di atas dapat disimpulkan bahwa aspek kualitas pembelajaran yeng terdiri dari iklim kelas dan motivasi belajar siswa mengalami peningkatan. Perubahan persentase capaian seluruh aspek kualitas pembelajaran dari pra siklus, sampai siklus II tersaji dalam Tabel 3 dan Gambar 4.

Tabel 3. Perbandingan Capaian Kualitas Pembelajaran Pra Siklus, Siklus I, dan Siklus II

\begin{tabular}{ll}
\hline \multicolumn{1}{c}{ Tindakan } & $\begin{array}{c}\text { Capaian Kualitas } \\
\text { Pembelajaran Biologi }\end{array}$ \\
\hline Pra Siklus & $62,90 \%$ \\
\hline Siklus I & $75,37 \%$ \\
\hline Siklus II & $80,77 \%$ \\
\hline
\end{tabular}

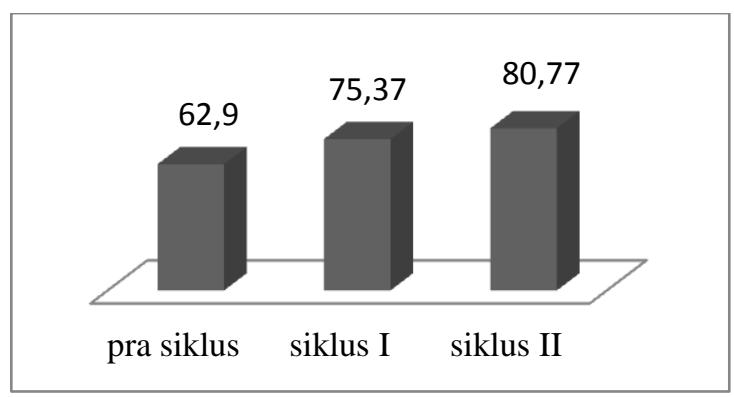

Gambar 4. Perubahan Persentase Capaian Kualitas Pembelajaran Biologi Pra Siklus, Siklus I, dan siklus II

Hasil analisis menunjukkan bahwa penerapan model experiential dalam pembelajaran dapat meningkatkan kualitas pembelajaran biologi yang meliputi iklim kelas, motivasi belajar siswa, dan pemanfaatan fasilitas pembelajaran.

Model experiential learning merupakan model pembelajaran yang diharapkan dapat menciptakan proses belajar yang lebih bermakna. Melalui model ini, siswa tidak hanya belajar tentang konsep materi belaka, hal ini dikarenakan siswa dilibatkan secara langsung dalam proses pembelajaran untuk dijadikan sebagai suatu pengalaman.

Menurut Marlow dan McLain (2008) experiential learning adalah sebuah proses yang dialami oleh peserta didik dalam mengkonstruksi pengetahuan, keterampilan, dan nilai secara langsung dari pengalaman yang diperoleh. Penggunaan model ini dapat meningkatkan pemahaman yang lebih dalam bagi peserta didik. Muqhal (2011) juga mengungkapkan bahwa pembelajaran experiential merupakan pembelajaran konstruktivistik yang mengarahkan peserta didik untuk membangun pengetahuannya sendiri melalui pengalaman.

Model experiential learning memungkinkan siswa untuk aktif terlibat dalam pembelajaran sehingga pembelajaran terjadi dua arah. Motivasi yang baik membuat siswa lebih antusias untuk mengikuti pembelajaran, dan akan memunculkan iklim kelas yang baik. Hal ini senada dengan yang diungkapkan oleh Millenbah, K.F \& Millspauqh, J.J (2003) yaitu bahwa pembelajaran experiential dapat meningkatkan motivasi siswa yaitu melalui pengalaman-pengalaman yang dialami oleh siswa. Penggunaan model ini juga dapat meningkatkan retensi, kemampuan problem solving, dan 
kemampuan mengambil keputusan yang dimiliki siswa.

$$
\text { Blazek, et al. (2013) juga }
$$
melaporkan bahwa penerapan model experiential learning di kelas dengan materi genetika menunjukkan hasil yaitu dapat membantu siswa untuk lebih memahami materi genetika melalui aktivitas-aktivitas experiential yang dialami oleh siswa.

Hasil penelitian menunjukkan bahwa penerapan model experiential learning dapat meningkatkan kualitas pembelajaran bioloogi siswa kelas XI IPA 1 SMA Negeri 2 Surakarta sesuai target yang telah ditentukan. Hasil penelitian ini sejalan dengan penelitian yang dilakukan oleh Anggara (2012) terkait model experiential learning. Hasil penelitian tersebut menyimpulkan bahwa terdapat perbedaan konsep diri dan pemahaman konsep antara kelompok siswa yang belajar dengan model pembelajaran experiential dan model pembelajaran konvensional.

Penelitian lain yang sejalan juga dilakukan oleh Fatmawati (2013) yang mengungkapkan bahwa penerapan model experiential learning dapat meningkatkan hasil belajar siswa kelas XI IPA SMA Taruna Nusantara Magelang.

Hasil penelitian ini juga didukung oleh Wiandariyani, dkk (2012) dan Utami, dkk (2013) yang menyatakan bahwa motivasi dan hasil belajar IPA siswa yang mengikuti pembelajaran experiential lebih tinggi dibandingkan dengan siswa yang mengikuti pembelajaran konvensional.

Penelitian lain yang dilakukan oleh Rahayu dan Rohayati (2013) menyatakan bahwa model experiential learning dapat menigkatkan softskills mahasiswa.

Penelitian lain yang dilakukan oleh Clark, et al. (2010) menunjukkan bahwa pembelajaran menggunakan experiential learning dapat meningkatkan retensi siswa. Sedangkan Arnold, et al. (2006) mengungkapkan bahwa pembelajaran experiential mampu meningkatkan retensi siswa, pembelajaran menjadi lebih menyenangkan, siswa menjadi lebih aktif, dan peningkatan high order thinking skill dalam setiap aktivitas pembelajarannya.

\section{Simpulan}

Berdasarkan hasil penelitian dapat diambil beberapa kesimpulan sebagai berikut:

1. Penerapan model experiential learning di kelas XI IPA 1 SMA Negeri 2 Surakarta tahun pelajaran 2013/2014 mampu meningkatkan kualitas pembelajaran biologi siswa yang terdiri dari 3 aspek:

a. Kemanfaatan sarana dan prasarana pembelajaran, dilihat dari penggunaan fasilitas yang sudah cukup optimal, antara lain penggunaan mikroskop dan media pembelajaran seperti gambar dan 
video sebagai salah satu media yang dapat mendukung pembelajaran.

b. Iklim kelas: persentase capaian pra siklus $(62,59 \%)$, siklus I $(75,86 \%)$, dan siklus II (82,92\%).

c. Motivasi belajar siswa: persentase capaian pra siklus $(63,22 \%)$, siklus I $(74,88 \%)$, dan siklus II $(78,62 \%)$.

2. Capaian persentase kualitas pembelajaran pra siklus $(62,90 \%)$, siklus I (75,37 \%), siklus II (80,77\%).

3. Besarnya peningkatan capaian kualitas pembelajaran dari pra siklus sampai siklus II adalah sebesar 17,87 \%.

\section{Daftar Pustaka}

Anggara, A \& Komang, I. (2012). Pengaruh Model Pembelajaran Experiential terhadap Konsep Diri dan Pemahaman Konsep Fisika Siswa Kelas X SMA Negeri 4 Singaraja. (Laporan penelitian tidak dipublikasikan. Universitas Pendidikan Ganesha)

Arnold, S, et al. (2006). Experiential Learning In Secondary Agricultural Education Classrooms [Electronic version]. Journal of Sothertn Agricultural Education Research, 56 (1).

Blazek, J.D et al. (2013). Trying Out Genes for size: Experiential Learning in the High School Classroom [Electronic version]. Journal of American Education, 75(9).

Budiman, I. (2011). Model Pembelajaran Experiential Learning. http:// fisikasma-online.blogspot.com /2010/model-pembelajaranexperiential. 02/5/2014

Clark, et al (2010). The Potential Experiential Learning Models and Practices In Carrer and Technical Education [Electronic version]. Journal of Carrer and Technical Education, 25(2).
Djamarah, S.B and Zain. (2010). Strategi Belajar Mengajar. Jakarta: Rineka Cipta

Ewert, A., and Sibthorp, J. (2009). Creating Outcomes through Experiential Education: The Challenge of Confounding Variables [Electronic version]. Journal of Experiential Education, 31(3), 376389

Fatmawati, D.N. (2013). Pengembangan Model Pembelajaran Experiential Learning yang Diarahkan untuk Strategi Pembelajaran Think Talk Write pada Materi Sistem Saraf di Kelas XI IPA SMA Taruna Nusantara Magelang. (Thesis Tidak dipublikasikan, Universitas Sebelas Maret, Surakarta)

Hamalik, O. (2008). Proses Belajar Mengajar. Jakarta: Sinar Grafika

Kolb, D. (1984). Experiential Learning. Upper Saddle: New Jersey. http://academic.regis.edu/ed205/kolb.pd f. $02 / 11 / 2014$.

Lalonde, C. (2010). Experiential Learning. Faculty, Practical Nursing Owen Sound Campus, Centre for Teaching and Learning. http://www2.glos.ac.uk/gdn/ gibbs/ch2.htm. 02/13/2014

Mahfud, A. (2011). Model Pembelajaran Experiential Learning. http:// albyjmahfudz.blogspot.com/2011/05/m odel-pembelajaran-experiential. 02/5/2014

Marlow, M.P and Mclain B. (2008). Assesing the impacts of experiential learning on teacher classroom practice. Research in Higher Education Journal . http://www.georgiancollege/experientia 1 learning 03/10/2014

Millenbah, K.F and Millspauqh, J.J. (2003). Using experiential learning to improve retention, problem solving, and decision making [Electronic version]. Journal of Learning and Education, 31(1).

Mulyasa, E. (2007). Kurikulum Tingkat Satuan Pendidikan. Bandung: Remaja Rosdakarya

Muqhal, F. (2011). Experiential Learning from a Constructivistict Perspective: 
Reconceptualizing the Kolbian Cycle [Electronic version]. International Journal of Learning and Development, 1(2).

Prawira, P.A. (2012). Psikologi Pendidikan dalam Perspektif Baru. Yogyakarta: Ar-Ruzz Media

Rahayu and Rohayati. (2013). Implementasi Metode Experiential Learning dalam Pengembangan Softskill Mahasiswa yang Menunjang Integrasi Teknologi, Manajemen dan Bisnis [Electronic version]. Jurnal Penelitian Pendidikan, 14 (1).

Tarmidi. (2006). Iklim dan Prestasi Belajar. Medan: USU Repository

Trianto. (2010). Mendesain Model Pembelajaran Inovatif-Progresif. Jakarta: Kencana
Uno, H.B. (2008). Teori Motivasi dan Pengukurannya. Jakarta: Bumi Aksara

Utami (2012). Pengaruh Model Experiential Learning berbantuan media benda asli terhadap Hasil Belajar Siswa Kelas IV SD Gugus 1 Kecamatan Tabanan. (Laporan Penelitian Tidak dipublikasikan. Universitas Pendidikan Ganesha)

Wiandariyani, dkk. (2012). Pengaruh Model Pembelajaran Experiential Learning terhadap Motivasi dan Hasil Belajar IPA Siswa Kelas V SD N Banjar Tegal Kecamatan Buleleng. (Laporan Penelitian Tidak dipublikasikan. Universitas Pendidikan Ganesha)

Widoyoko, E.P. (2010). Evaluasi Program Pembelajaran. Yogyakarta: Pustaka Pelajar 